Agro-Science Journal of Tropical Agriculture, Food, Environment and Extension Volume 18 Number 2 (May 2019) pp. 1-7

ISSN 1119-7455

\title{
EFFICIENCY OF GARRI MARKETING IN KWARA STATE, NIGERIA: IMPLICATION FOR ECONOMIC EMPOWERMENT
}

\author{
${ }^{1}$ Isitor S.U., ${ }^{2}$ Babalola D.A. and ${ }^{1}$ Abegunde T.E. \\ ${ }^{1}$ Department of Agricultural Economics and Extension \\ Landmark University, Omu Aran, Kwara State, Nigeria \\ ${ }^{2}$ Department of Agriculture and Industrial Technology, \\ Babcock University, Ilishan-Remo, Ogun State Nigeria
}

\begin{abstract}
ABSRACT
Nigeria is the largest producer of cassava in the world. Marketing of garri, a major product from cassava, has potential for economic empowerment in Nigeria. The study analyzed the efficiency of garri marketing in Nigeria based on evidence from Kwara State. Data for the study was collected from 120 respondents and analyzed using budgetary and regression techniques. The results showed that most of the respondents were uneducated women who relied on personal savings to finance their agribusiness. Marketing efficiency was 1.12 indicating efficient marketing system which implies that the enterprise is profitable with huge potential for economic empowerment. Factors influencing profitability of garri enterprise (significantly at $P \leq 0.05$ ) included cooperative participation and experience in garri marketing. Major reported marketing constraint included price fluctuation. In order to further improve profitability, hence the potential of garri enterprise for economic empowerment, this paper recommends increasing respondents' access to more formal financial intermediaries, especially the cooperatives.
\end{abstract}

Key words: cassava, marketing efficiency, profitability, Nigeria

\section{INTRODUCTION}

In meeting the Sustainable Development Goals (SDGs) of food security in Nigeria and fostering economic empowerment, the cassava value chain development have been identified because of the country's huge potential for cassava production and the growing global demands (AfDB, 2015). Abubakar (2003) noted that the current trend in cassava production and demand showed that cassava production is increasing globally and that growing of cassava is expanding to the semi-arid areas where cassava was not cultivated 30 years ago. Production and processing of cassava in Nigeria is still predominantly local yet Nigeria is one of the largest producers of cassava and cassava products in Africa (Philip, Sanni and Akoroda, 2004; AfDB, 2015). Cassava is a basic food staple contributing about $40 \%$ of the food calories consumed in Africa (IITA, 1990). It is the third largest source of food carbohydrates in the tropics, after rice and maize (Fauqu et and Fargette, 1990). A major and most popular form in which cassava is processed and marketed in Nigeria is garri (Ezedinma, Okechukwu and Sanni, 2005). Garri can be described as a fermented and roasted granular product from cassava. Several studies have established the high acceptability and consumption of garri both in the rural and urban Nigeria (Phillip et al., 2004; Maziya - Dixon et al., 2004; Adebayo Lamboll, and Westby, 2009). Thus garri processing and marketing has the potential to contribute immensely to economic empowerment and the development of the downstream component of the agribusiness sector in Nigeria. However, inadequate marketing system for garri and other food commodities has been identified as a constraint to agricultural development in Nigeria, particularly in rural communities (Nweke, 1997; AfDB, 2015). Ezedinma, Okechukwu and Sanni (2005); Sanzidur and Brodrick (2016) observed that in Nigeria, garri prices exhibit cyclical peaks and troughs due mainly to the inability of markets to absorb supplies. As a result in the years when cassava is scarce the price goes up and farmers are encouraged to plant; production goes up in subsequent years and the price comes down prompting farmers to plant less until the price goes up again in a cycle of approximately two to three years. Such cyclical changes cause price instability, and significantly increase the income risk to producers, processors and other players is the cassava-garri value chain. High product price 
variations coupled with high transaction costs and risks in the cassava-garri marketing system predisposes it to poor linkage with the nonagricultural sectors which can cause disincentives for production and reduce export earnings (EEA, 2004). Studies have shown that efficient marketing system stimulates agricultural production (Awoyinka and Ikpi, 2005). However, marketing of food in Nigeria has been characterized by a lot of deficiencies (Adekanye, 1988; Adekanye, 2013). These deficiencies have constrained sustainable agricultural development in one way or the other.

In Nigeria, several policies related to the development of cassava production and processing have been initiated such as the Presidential Initiative on Cassava and the FADAMA projects. However, these initiatives have failed to adequately incorporate strategies for combating perennial constraints to effective and efficient cassava product marketing in Nigeria. There is also the problem of the exploitative tendencies of the middle men in the cassava product marketing chain. Isitor, Otunaiya and Iyanda (2016) observed that inadequate storage system has contributed to the persistence of the exploitation of the farmers by the middlemen. This has contributed to increased marketing costs and hence market inefficiency. It is also important to note that the more the number of the middlemen in the marketing chain (common scenario in Nigeria), the longer the length of the chain and the greater the difference in the price paid between consumers at the end of the chain and farm gate price at the beginning of the chain. This leads to greater or wider marketing margin between producers and final consumers. If the marketing margin is high, it may be used to argue that consumers are being exploited. However, high margin cannot often be fully justified unless costs are rational and fully understood (Ali, Gaya, and Jampada, 2007). In Nigeria, previous studies have focused on production efficiency and there have been scanty empirical studies on marketing efficiency of agricultural commodities such as garri. It is a known fact that market-driven production is imperative for sustainable growth. This study was therefore conducted to provide empirical information on the efficiency of garri marketing in Kwara State, Nigeria.

\section{Empirical Review of Literature}

Nduka and, Udah (2015) carried out a study to establish the nature of marketing and determinants of net returns to garri marketers, data were analyzed using descriptive statistics and ordinary least square regression technique. The study examined the marketing cost and returns of retailed garri, factors influencing the marketers' net returns, the problems associated with garri marketing and the socio-economic characteristics of the respondents. The regression result indicated that the significant determinants of net returns to garri included cost of garri purchased and transport cost. Provision of basic infrastructural facilities and formation of a viable cooperative society by the marketers were recommended based on this study.

Aidoo et al. (2012) assessed the marketing margins and efficiency of the major players in the yam marketing chain in Ghana. They discovered that yam distribution passes through more than three different channels from the farm gate to final consumers. Evidence from the study showed that the majority of yam farmers sold their produce in the main district market and only $20 \%$ sold yams at the farm gate. They also observed that selling in the market increased marketing margin hence efficiency. Furthermore, net marketing margin was highest for cross-border yam traders, followed by wholesalers. The net margins obtained by producer-sellers and retailers were less than half the margins obtained by cross border traders. Net marketing margin received by wholesalers was about $78 \%$ higher than that obtained by retailers and produce-sellers. Yam marketing activities among retailers, wholesalers and cross-border traders were highly efficient with efficiency figures greater than 1 (in excess of $100 \%$ ). However, yam marketing among producer-sellers was found to be inefficient with efficiency ratio of about 0.86 (86\%). Ugwumba (2009) examined the efficiency of fresh maize marketing and effects of socioeconomic and demographic factors on marketing margin in Anambra State. This study utilized descriptive statistic, Sherpherd - futrel (1969) model of determining marketing efficiency and multiple regression. He observed that fresh maize marketing business was dominated by women. Furthermore, the overall coefficient of marketing efficiency was 0.56 or $56.16 \%$. However, wholesalers were more efficient in marketing followed by the producers and lastly the retailers. Marketing margin was positively influenced by marital status, access to credit, marketing experience and savings. It was however, negatively affected by age, educational level, gender and marketing cost. Umoh (2006) previously employed the technique used by Ugwumba (2009) to estimate the profitability of urban farming and found that farming in urban area is not profitable enough to sustain an average farmer. Yusuf et al. (2010) also adopted this technique in determining the profitability of improved maize variety production in Sabon Gari Local Government of Kaduna State, Nigeria and found farming of improved maize variety to be profitable. Babalola et al.. (2015) studied the Economic Potential of fish marketing and women empowerment in Ogun state, Nigeria using marketing margin and regression techniques. Their study revealed marketing efficiency greater than one which indicated profitability of the enterprise and further showed that fish marketing 
has the potential to contribution to women's economic empowerment. The regression results showed that the variables which positively and significantly influenced marketing margin among fish marketers were the value of sales per week, volume of trade per week, level of education and participation in cooperative marketing. The cost of fish purchase negatively and significantly influenced marketing margin. Isitor et al. (2015) studied the efficiency of vegetable marketing in Ifo and Ado-Odo L.G.As of Ogun State, Nigeria. Analytical tools used included, descriptive statistics, budgetary techniques and marketing efficiency. The Marketing Efficiency scores indicated that the marketing system of local vegetables in Ifo and Ado-Odo LGAs are efficient with that of fluted pumpkin being more efficient than the other vegetables.

\section{MATERIAL AND METHODS}

The study was carried out in Ekiti Local Government Area (LGA) in Kwara State, Nigeria. The study area has an area of $480 \mathrm{~km}^{2}$ and a population of 54,850 as at the 2006 census. The people of Ekiti local government are predominantly traders and generally Garri marketers. Small scale farming activities is also common in the study area. The choice of the study area was based on the huge contribution to garri processing and distribution.

\section{Methods of Data Collection and Sampling Technique}

Primary data were used for the study and obtained through the administration of structured questionnaire.

A multistage sampling technique was adopted in the study. The first stage of the sampling procedure involved the purposive selection of 6 communities or towns from among the 12 towns in Ekiti local government based on the population of garri marketers in the areas. Communities selected included Isapa, Obo - ile, Obo aiyegunle Osi, Etan, and Isare - opin. In the second stage, 20 respondents (garri marketers) were selected randomly from each selected communities. Thus, a total of 120 respondents were selected for the study.

\footnotetext{
Methods of Data Analysis and Model Specification

Data gathered were analyzed using descriptive statistics such as frequency and percentage distribution to present the socio-economic characteristics of the marketers. Budgetary technique and the multiple regression analysis were also employed in the study. The budgetary technique involving cost and return analysis was used to determine the Marketing Margin (MM) and the Marketing Efficiency (ME) of the garri marketers. The model specification is given as:
}

$\mathrm{MM}=\mathrm{TR}-\mathrm{TC}$

$\mathrm{ME}=\mathrm{TR} / \mathrm{TC}$.

where:

TR - Total Revenue (

TC -Total Cost ( consist of the cost of purchase in naira, the cost of storage in naira per month and the cost of transportation in naira per month); MM - Marketing Margin (N) (which is the proxy for profitability) and ME - Marketing Efficiency. The multiple regression analysis was employed to determine the influence of the socio economic factors, purchase price and other marketing costs on garri marketing margin. This was done to establish the determinants of profitability of garri in the study area. The relationship between the endogenous and exogenous variables was specified as follows:

Y-f $\left(X_{1}, X_{2}, X_{3}, X_{4}, X_{5}, e\right)$

where;

Y - Marketing Margin ( $\mathrm{N}$ )

$\mathrm{X}_{1}$ - Age of marketers in years

$\mathrm{X}_{2}$ - Level of education in years

$\mathrm{X}_{3}$ - Experience of respondents in trading garri (yrs)

$\mathrm{X}_{4}$ - colour of garri

$\mathrm{X}_{5}$ - membership of co-operatives

e - error term.

Following Olayemi (1998), the relationship between the endogenous variable and each of the exogenous variables were examined using linear, exponential, semi-logarithm and Cob-Douglas (double logarithm) functional forms. The lead equation was chosen based on the value of the coefficient of determination $\left(\mathrm{R}^{2}\right)$, statistical significance and economic theory that support garri marketing. The equations can be explicitly stated as:

Linear: $\mathrm{Y}-\mathrm{b}_{0}+\mathrm{b}_{1} \mathrm{X}_{1}+\mathrm{b}_{2} \mathrm{X}_{2}+\ldots+\mathrm{b}_{5} \mathrm{X}_{5}+\mathrm{e} \ldots$... (4) Semi-log: $Y-\log b_{0}+b_{1} \log X_{1}+b_{2} \log X_{2}+\ldots+$ $\mathrm{b}_{5} \log \mathrm{X}_{5}+\log \mathrm{e}$.

Exponential: $\log \mathrm{Y}-\mathrm{b}_{0}+\mathrm{b}_{1} \mathrm{X}_{1}+\mathrm{b}_{2} \mathrm{X}_{2}+\ldots+\mathrm{b}_{5} \mathrm{X}_{5}$

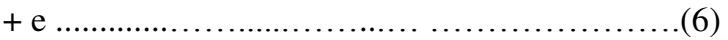

Cob-Douglas: $\log \mathrm{Y}-\log \mathrm{b}_{0}+\mathrm{b}_{1} \log \mathrm{X}_{1}+\mathrm{b}_{2} \log \mathrm{X}_{2}$ $+\ldots+\mathrm{b}_{5} \log \mathrm{X}_{5}+\log \mathrm{e}$.

Also, the marketing channels of garri in the study area were identified and presented in pictorial form.

\section{RESULTS AND DISCUSSION}

Respondents' Descriptive result

Result in Table 1 shows that the majority of the respondents were married $(61 \%)$, female $(98 \%)$ between ages 41 and 50 years old ( $43 \%$ with mean age - 46.5 \pm 8.2 ). The age of the respondents (as well as experience) is an important factor that can affect their level of efficiency and overall coping ability 
within the business (Oputa, 2005). This is particularly applicable to the study group since most of the respondents have over 10 years of experience in garri marketing $(79 \%$ with mean experience - 16.3 \pm 2.54$)$. Older garri marketers (which are a reflection of the study group) develop better management skills and marketing strategies over time. The gender distribution shows that garri processing and marketing is a female dominated enterprise in the study area. Measures that enhance efficiency and profitability of the garri business will go a long way to enhance women empowerment in the study area. Average household size was approximately 6 which is above the national average of approximately 5 (Babalola, 2014; NBS, 2007). It has been observed that large family size may imply more supply of labour hence reducing money spent to hire labour (Nwaru, 2006; Okolo, 2007). However, Babalola and Babalola (2013); Gebremedehin and Swinton (2003), opined that with increasing household size, respondents tend to divert funds originally meant for enterprise expansion to cater for domestic household needs. Some $71 \%$ of the respondents had formal education even though most $(34 \%)$ were at primary level. Level of formal education plays an important role in business management because it determines the degree of adoption of innovation and new technologies. It also determines the degree of excellences of individuals when performing business activities. Higher level of literacy and experience often translates to better marketing strategies leading to higher profits (FAO, 2006). Apparently, most of the respondents have high level of experience in garri marketing with some 46 percent having between 10 and 20 years of experience marketing garri (mean experience $16.3 \pm 2.54$ years). Therefore, it is expected that the respondents exhibit moderate to high efficiencies in garri marketing being the major occupation among the majority of them (85\%).

Table 1: Garri marketers' personal characteristics

\begin{tabular}{|c|c|c|c|}
\hline Variables & Freq $(n=120)$ & $(\%)$ & Mean $( \pm$ SD) \\
\hline Married respondents & 73 & 60.8 & \\
\hline \multicolumn{4}{|l|}{ Gender: } \\
\hline Male & 2 & 1.7 & \\
\hline Female & 118 & 98.3 & \\
\hline Age (years) & & & $46.5( \pm 8.2)$ \\
\hline$<30$ & 4 & 3.3 & \\
\hline $30-40$ & 44 & 36.7 & \\
\hline $41-50$ & 52 & 43.3 & \\
\hline $51-60$ & 20 & 16.7 & \\
\hline \multicolumn{4}{|l|}{ Educational level: } \\
\hline None & 35 & 29.2 & \\
\hline Primary & 41 & 34.2 & \\
\hline Secondary & 40 & 33.3 & \\
\hline Tertiary & 4 & 3.3 & \\
\hline Household size & & & $5.96( \pm 2.04)$ \\
\hline $0-3$ & 4 & 3.3 & \\
\hline $4-6$ & 77 & 64.2 & \\
\hline $7-9$ & 34 & 28.3 & \\
\hline$>9$ & 5 & 4.2 & \\
\hline Experience (years) & & & $16.3( \pm 2.54)$ \\
\hline$<10$ & 25 & 20.8 & \\
\hline $10-20$ & 55 & 45.8 & \\
\hline$>20$ & 40 & 33.4 & \\
\hline Participation in co-op & 42 & 35.0 & \\
\hline \multicolumn{4}{|l|}{ Major occupation: } \\
\hline Garri marketing & 102 & 85.0 & \\
\hline Farming & 3 & 2.5 & \\
\hline Trading & 10 & 8.3 & \\
\hline Civil servant & 5 & 4.2 & \\
\hline \multicolumn{4}{|l|}{ Source of finance: } \\
\hline Personal savings & 74 & 61.7 & \\
\hline Gift/loan from friends \& relatives & 5 & 4.2 & \\
\hline Loan from commercial banks & 1 & 0.8 & \\
\hline Loan from cooperatives societies & 39 & 32.5 & \\
\hline Loan from microfinance banks & 1 & 0.8 & \\
\hline \multicolumn{4}{|l|}{ Garri sales point } \\
\hline Market in stall & 39 & 32.5 & \\
\hline Hawking & 2 & 1.7 & \\
\hline Rented/owned shops & 30 & 25.0 & \\
\hline Contract arrangement & 49 & 40.8 & \\
\hline
\end{tabular}

Source: Field survey (2017) 
The result also shows that only 35 percent of the marketers actively participate in one form of cooperative or another. This explains why only 33 percent have benefitted from cooperative loans. The importance of cooperatives in providing information that can enhance business management skills of members, assist members achieve higher marketing efficiencies and provide credit access, have been detailed in past studies (Nto et al., 2011; Ayinde et al., 2008).

\section{Marketing Channels of Garri Marketing}

Although 33 percent of the respondents sell their garri in their market stalls, some 41 per cent rely on contract arrangement in distributing their garri (see Table 1). This result suggests that the respondents engage in large volume of sales. Further analysis of the marketing channel for garri in the study area, as presented in figure 1 , shows the important and systematic role played by the different market intermediaries in garri distribution from production to final consumption. The use of a marketing channel is convenient particularly when the producer does not have the time or financial means to carry out direct marketing. Intermediaries are usually able to make the product widely available and accessible because they are specialized and have experience and contacts. Intermediaries take the risks involved in marketing and also pay for the produce immediately (Boundless, 2015).

\section{Results of Budgetary Analysis for Marketing Margin and Efficiency}

The result of the budgetary analysis of garri marketing as presented in Table 2 shows that the average marketing margin for the marketers, which was used as proxy for profitability, was estimated to be $\$ 3,296.83$ per $50-\mathrm{kg}$ bag. Available information shows that profit on a bag of garri in Nigeria was between $\$ 2,500$ and $\$ 3,000$ as at the time this study was conducted (Yuusuph, 2017; Naira land, 2016). Thus, garri marketing is a relatively profitable venture in the study area. The marketing efficiency score was (1.12) which is greater than 1, thereby indicating that garri marketing in the study area is also efficient. This result is consistent with Isitor et al. (2016) who reported marketing efficiency scores greater than 1 for various agricultural products in Nigeria including garri indicating the potential of garri marketing for economic empowerment.

\section{Factors Influencing Variations in Marketing Margin}

The regression analysis was used to predict the influence of the hypothesized explanatory variables on the marketing margin. The analysis was subjected to four functionalformsas stated in the methodology. Based on the result of the diagnostic tests, the Cobb-Douglas functional form was selected as the lead equation due to the fact that it has the highest adjusted coefficient of determination $\left(\mathrm{R}^{-2}\right)$ and number of the significant variables. From the result of the analysis, the $\mathrm{R}^{-2}$ is 0.75 indicating that 75.0 percent of the variation in the marketing margin is explained by the variations in the specified independent variables. The Fstatistic of 38.50 is significant at $1 \%$ level, indicating that the model has goodness of fit. The regression result (Table 3) shows that the coefficient of the level of experience in garri marketing (2.430) is positive and statistically significant at $5.0 \%(\mathrm{p}<0.05)$. Also, the coefficient of respondents' membership and participation in cooperatives (2.042) is positive and statistically significant at $1.0 \%(\mathrm{p}<0.01)$. The signs of these variables conform to apriori expectation.

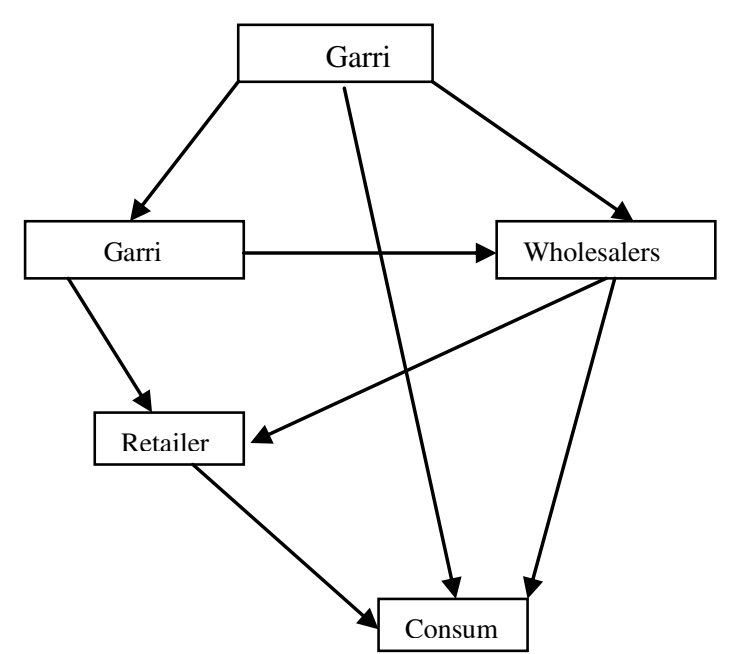

Figure 1: Marketing channel for garri in Ekiti LGA Source: From field Survey (2017).

Table 2: Marketing margin and efficiency of garri marketers

\begin{tabular}{ll}
\hline & Value in naira per marketer per \\
& $50 \mathrm{~kg} \mathrm{bag}$ \\
\hline Total cost (a) & $\mathbf{2} 28535.67$ \\
Total revenue (b) & 31832.5 \\
Marketing margin (b-a) & 3296.83 \\
Marketing efficiency(b/a) & 1.12 \\
\hline \multicolumn{2}{l}{ Source: Computed from field survey (2017). }
\end{tabular}

Table 3: Regression result for determinants of garri profitability among respondents

\begin{tabular}{ll}
\hline Variables & Coefficient (t-value) \\
\hline Onstant & $-1.055(0.1531)$ \\
Age of marketers & $0.734(0.154)$ \\
Level of education & $0.065(0.631)$ \\
Experience in garri marketing & $2.430^{* *}(1.988)$ \\
colour of garri & $1.044(0.702)$ \\
Membership of co-operatives & $2.042^{* * *}(3.162)$ \\
Adjusted $\mathrm{R}^{2}$ & 0.75 \\
F-statistics & $38.50 * * *$ \\
\hline$* * *$ Coefficient significant at 1.0\%; **Coefficient is significant \\
at 5.0\% Source: computed field Survey (2017).
\end{tabular}


Table 4: Common constraints to garri marketing in the study area

\begin{tabular}{llll}
\hline Constraints & Severe (\%) & Mild (\%) & Not a constraint (\%) \\
\hline Price fluctuations /instability & $84(70.0)$ & $35(29.3)$ & $1(0.8)$ \\
Insufficient fund & $64(53.3)$ & $50(41.7)$ & $6(5.0)$ \\
Middle men problem & $56(46.7)$ & $41(34.2)$ & $23(19.1)$ \\
High cost of transportation & $50(41.7)$ & $49(40.9)$ & $21(17.5)$ \\
Low level of demand & $24(20.0)$ & $85(70.8)$ & $11(9.20)$ \\
High cost of storage & $19(15.9)$ & $61(50.8)$ & $40(33.3)$ \\
\hline
\end{tabular}

Source: From field Survey (2016).

The result implies that a percentage increase in these factors will yield $2.430 \%$ and $2.042 \%$ increases in the marketing margin respectively. Indicating that the more experienced the marketers are, the more they are able to take rational decision that will increase profitability (market margin).This is in line with the findings of Ozigbo (2011). Also, the result implies that participation in cooperative will boost profitability of garri marketing. Key functions of the cooperatives are to assist individual members in financing their enterprise and marketing their produce profitably. Unfortunately, as earlier reported, majority of the marketers still do not participate in cooperatives.

\section{Constraints in Garri Marketing}

The respondents were asked to indicate the common constraints they faced in garri marketing and to rate the severity of these constraints. The result of respondents' ranking of constraints in marketing is presented in Table 4. The constraint that the majority of the respondents $(70 \%)$ reported as most severe was price fluctuation. As earlier highlighted, the price received by garri entrepreneurs in Nigeria varies throughout the year. Garri is usually cheapest in the months of July to September and becomes expensive as from December to April (Ezedinma, Okechukwu and Sanni, 2005) this, coupled with its perishable nature, often discourage stocking in large volume. This increases income risks not just to marketers of garri but to the producers of cassava.

\section{CONCLUSION AND RECOMMENDATION}

The study examined the efficiency of garri marketing in Ekiti L.G.As of kwara State, Nigeria. From the findings of the study, it is clear that women were the major players in the garri enterprise. Thus efforts at enhancing profitability and efficiency will enhance the economic wellbeing of the female folks. The study revealed that garri marketing business is profitable. The marketing of garri in the study area is also efficient. However, price fluctuation was reported as a major severe constraint to garri marketing. Based on the findings the following have been recommended:

1. Respondents' participation in cooperatives can reduce the exploitative influence of middlemen in the garri distribution channel, facilitate access to useful funds and even reduce cost of transportation per marketer. Thus respondents should be encouraged to participate more in cooperatives. Further studies should assess the barriers to participations and ways to ameliorate.

2. Government should be deliberate and more intentional about policy reforms facilitating price stability especially for agricultural products such as cassava. This will further encourage stability of investment in the enterprise consequently expanding its potential for economic empowerment.

3. Basic infrastructural facilities such as good rural roads network to curtail marketing cost and credit facilities to meet the financial needs of the marketers should be provided to enhance marketing efficiency.

\section{REFERENCES}

Abubakar A. (2003). Employment creation and opportunities in the Agro-Allied Sub-Sector- The Case of Cassava production. Central Bank of Nigeria Bullion., 27 (4), 1-10

Adebayo K., Lamboll R.I and Westby A. (2009). Contextualizing environmental social and behavioural issues in the cassava post-harvest systems in Africa. Anthropologist special 5, 137146

Adekanye T.O. (2013). The markets for food stuffs in Western Nigeria, J. Afri. Studies.,3 (1), 71-76

Adekanye T.O. (1988). The Markets for Foodstuff in Western Nigeria In: TO Adekanye (Eds.): Readings in Agricultural Marketing. Ibadan: Longman, pp.1222.

AfDB (2015). Economic Empowerment of African Women through Equitable Participation in Agricultural Value Chains, African Development Bank Publication, p. 5. Retrieved from www.afdb.org

Aidoo R., Nimoh F., Bakang A., Ohene-yankyera K., Fialor S., Mensah J. and Abaidoo R. (2012). Estimations of margins and efficiency in the Ghanaian yam marketing chain. Asian J. of Agri. and Rural Dev.,2 (2), 226-234

Ali E., Gaya H. and Jampada N. (2007). Economic Analysis of Fresh Marketing in Maiduguri $J$. of Agri. \& Soc. Sci.,4 (2), 3-6.

Awoyinka Y.A. and Ikpi A.E (2004). Economics of Farm Income and Technical Efficiency Resources in Jigawa State Industrial Sugar Cane Project, $J$ of Eco.\& Rural Dev., 14 (2), 96-100

Babalola D.A. (2014). Determinants of Farmers' Adoption of Agricultural Insurance: the Case of Poultry Farmers in Abeokuta Metropolis of Ogun State, Nigeria. British J. Poultry Sci.,3 (2), 36-41 
Babalola D.A. and Babalola Y. (2013). Economic effects of media campaign against pandemic diseases: the case of bird flu (H5N1) on poultry business in Ogun state, Nigeria. Arabian J. Business \& Mgt. Review.,2 (12), 80-88.

Babalola D.A., Bajimi O. and Isitor S.U. (2015). Economic potential of fish marketing and women empowerment in Nigeria: evidence from Ogun state. Afri. J. of Food, Agric, Nutri. and Dev.,15 (2), $9922-$ 9934

Boundless (2015). Types of Marketing Channels: Boundless Marketing. Retrieved Apr. 2016 from www.boundless.com/marketing/textbooks

EEA (2004). Industrialization and industrial policy in Ethiopia: Report on the Ethiopian Economy, Vol. III 2003/04. Ethiopian Economic Association/Ethiopian Economic Policy Research Institute, Addis Ababa

Ezedinma C., Okechukwu R. and Sanni L.(2005).Marketing of gari in Benin City and Enugu, Nigeria, In: Porter, G and F Lyon (Eds). Investigations on Building a Food Marketing Policy Evidence Base in Nigeria, 7, 121-141 accessed from www.dur.ac.ukSeptember 2006.

FAO (2006). FAO Year Book, Vegetable Seed Production Vegetable Research and Training Institute Vol. 40 (136), Rome, FAO of the United Nation.

Fauquet C, Fargette D. (1990). African Cassava Mosaic Virus: Etiology, Epidemiology and Control. Plant Disease.,74 (6), 404-11.

Gebremedhin B. and Swinton S.M. (2003). Investment in soil conservation in Northern Ethiopia: The role of land tenure security and public programs. Agri. Econ., 29, 69-84.

IITA (1990). The Research Horizon for Cassava as a Cash Crop. Annual report, International Institute for Tropical Agriculture., pp. 9 - 11 .

Isitor S.U, Otunaiya and Iyanda (2016). Efficiency of Vegetable Marketing in Peri-Urban Areas of Ogun State, Nigeria J. Agri. Sci.,8 (3), 109-120

Maziya-Dixon B., Akinyele I.O., Oguntona E.B., Nokoe S., Sanusi R.A. and Harriss E. (2004). Nigeria Food Consumption and Nutrition Survey 20012003.Summary Report of International Institute of Tropical Agriculture, Ibadan, Nigeria.

Nairaland (2006). How profitable is garri processing in Nigeria? Nairaland investment forum. Retrieved March 2018 from www.nairaland.com

NBS (2007). Nigeria Bureau of Statistics Annual Abstract of Statistics. 2006 Population Cencus., pp. 5-34.
Nduka M.U.1. and Udah S.C. (2015). Marketing Margin and Determinants of Net Returns to Garri Marketers in Ohafia Local Government Area, Abia State, Nigeria. Retrieved from http://www.openscienceonline.com/journal/ajbem

Nto P.O.O., Mbanasor J.A. and Nwaru J.C. (2011). Analysis of Risk among Agribusiness Enterprises Investment in Abia State, Nigeria. J. Econ.\& Int'l Finance., 3 (3), 187-194

Nwaru J.C. (2006). A Technical Efficiency Differentials on Cooperative and Non Cooperative Firms: Implication for Food Security in Nigeria. Nigerian J. of Agri., Teachers Educ., 19 (1), 21-29

Nweke F.I. (1997). Cassava is A Cash Crop in Africa: A View Point; IITA Research, No 14/15: pp. 26-27.

Okolo O.E. (2007). Economic analysis of broiler production in Jos Plateau State. Dissertation submitted to Amadu Bello University, Nigeria.

Oputa C.O. (2005). Resource Use and efficiency of artisanal fishing in Oguka Local Government Area of Imo State. A Project Report Submitted to Department of Agriculture, Abia State University, Umuahia Location.

Olayemi J.K. (1998). .Elements of Applied Econometrics.Ibadan University Press, Nigeria.

Ozigbo M.C. (2011). Economic of Marketing of Selected Salad Vegetable in Umuahia Local Government Area of AbiaState Nigeria. Bsc. Project Department of Agricultural Economics and Extension Abia State University, umuahia.

Philip T.P., Sanni L.O. and Akoroda M. (2004). Cassava; An industrial crop. IITA, Ibadan.

Sanzidur R. and Brodrick A. (2016). Exploring the potential of cassava in promoting agricultural growth in Nigeria, J. Agric. \& Rural Dev. in the Tropics and Subtropics, 117 (1), 149-163

Ugwumba C.O.A. (2009). Analysis of fresh maize marketing in Anambra State, Nigeria. J. on Res. in National Dev., 7 (7), 56-66.

Umoh G.S. (2006). Resource use Efficiency in Urban Farming: An Application of Stochastic Frontier Production Function. Int'l J. Agri.\& Biol., 8 (1): 3844.

Yusuf O., Adebayo C. and Sanni A. (2010). Economic evaluation of improved maize variety production in Sabon Gari LGA of Kaduna state, Nigeria. In: Baba K.M, Mohammed U.S, Nmadu J.N (eds) Commercial Agriculture Banking Reform and Economic Downturn: Setting a New Agenda for Agricultural Development in Nigeria. Proceeding of $11^{\text {th }}$ Annual Conference of National Assoc. of Agricultural Eco. December 2010.pp 121-135

Yuusuph (2017). A business proposal on cassava farming and garri production in Nigeria. Retrieved from www.agroraf.com 